\title{
AKTIVITAS ANTIPIRETIK EKSTRAK ETANOL DAUN \\ MENGKUDU (Morinda citrifolia L.) PADA TIKUS PUTIH JANTAN (Rattus norvegicus) GALUR WISTAR YANG DIINDUKSI PEPTON 5\%
}

\section{ANTIPYRETIC ACTIVITYOF ETHANOL EXTRACT OF NONI (Morinda citrifolia L.) LEAVES ON WISTAR MALE WHITE RATS (Rattus norvegicus) INDUCED PEPTONE 5\%}

\author{
Sulastri Herdaningsih ${ }^{*}$, Fenny Oktaviyeni, Ismi Utari \\ Akademi Farmasi Yarsi Pontianak \\ Jl. Panglima A'im Pontianak Kalimantan Barat 78232
}

Submitte : 27 Desember 2018

Review : 23 Januari 2018

Accepted : 18 Maret 2019

\begin{abstract}
ABSTRAK
Mengkudu sebagai salah satu tanaman yang mengandung senyawa flavonoid dan berkhasiat sebagai penurun suhu panas/demam (antipiretik). Penelitian ini bertujuan untuk menguji aktivitas antipiretik ekstrak etanol daun mengkudu (Morinda citrifolia L.) terhadap tikus putih jantan (Rattus norvegicus) galur wistar yang diinduksi pepton 5\% serta menentukan konsentrasi yang paling baik terhadap aktivitas antipiretik ekstrak etanol daun mengkudu (Morinda citrifolia L.). Hewan uji yang digunakan sebanyak 20 ekor, yang dibagi menjadi 5 kelompok dengan 4 replikasi yaitu kontrol negatif (suspensi Na.CMC 1\%), kontrol positif (suspensi parasetamol) dan kelompok uji ekstrak etanol daun mengkudu (Morinda citrifolia L.) dengan dosis $18 \mathrm{~g} / \mathrm{KgBB}, 36 \mathrm{~g} / \mathrm{KgBB}$, dan $72 \mathrm{~g} / \mathrm{KgBB}$. Data yang diperoleh dianalisis dengan menggunakan uji ANOVA dan LSD. Hasil penelitian menunjukkan bahwa pada dosis $72 \mathrm{~g} / \mathrm{KgBB}$ ekstrak etanol daun mengkudu (Morinda citrifolia L.) memiliki aktivitas antipiretik setara dengan suspensi parasetamol sebagai kontrol positif dengan persen daya antipiretik sebesar $80 \%$ dan nilai $\mathrm{p}$ value $0,703(\mathrm{p}>0,05)$, sedangkan pada kontrol negatif dengan persen daya antipiretik sebesar $17 \%$ dan nilai $\mathrm{p}$ value $0,003 \%(\mathrm{p}<0,05)$.
\end{abstract}

Kata Kunci : Ekstrak Etanol Daun Mengkudu (Morinda citrifolia L.), Aktivitas Antipiretik, Tikus Putih Jantan (Rattus norvegicus), Pepton

\begin{abstract}
Noni (Mengkudu) as one of the plants containing flavonoids and efficacious as a lowering temperature / fever (antipyretic). A research has been done about the experiment of antipyretic activityof ethanolic extract of noni leaves (Morinda citrifolia L.) that has been known to have flavonoid as antypiretic. The aim of this study was to examine the effect of ethanolic extract of noni leaves (Morinda citrifolia L.) as antypireticon Wistar male white rats (Rattus norvegicus) induced with pepton 5\% and to determine the best concentration antipiretyc activity of ethanolic extract from noni leaves (Morinda citrifolia L.). Tested animals were 20 rats, that will be divided into 5 groups with 4 replication, that is negative control (Na.CMC 1\% Suspension), positive control (Paracetamol Suspension) and treatment
\end{abstract}


group of noni leaves (Morinda citrifolia L.) with dose of $18 \mathrm{~g} / \mathrm{KgBB}, 36 \mathrm{~g} / \mathrm{KgBB}$, and 72 $\mathrm{g} / \mathrm{KgBB}$. Analyzed by Anova and LSD. The results showed $72 \mathrm{~g} / \mathrm{KgBB}$ of ethanolic extract of noni leaves (Morinda citrifolia L.) has antipyretic activity equivalent to paracetamol suspension as control positive with $80 \%$ antipyretic strength percentage with p-value 0,703 ( $p>0,05)$, while the negative control with percent antipyretic power is $17 \%$ and $p$ value is $0.003 \%(\mathrm{p}<0.05)$.

Keywords : Ethanol Extract of Noni Leaves (Morinda citrifolia L.), Antipyretic Activity, Male White Rats (Rattus norvegicus), Pepton 5\%.

\section{Penulis korespondensi:}

Sulastri Herdaningsih

Akademi Farmasi Yarsi Pontianak

Jl. Panglima A'im Pontianak Kalimantan Barat 78232

Email : sulastriherdaningsih08@gmail.com/No HP 085750821089

\section{PENDAHULUAN}

Demam sering dialami setiap orang. Demam adalah peningkatan suhu tubuh dari suhu normal tubuh. Suhu normal tubuh berkisar antara 36,5-37, $2^{\circ} \mathrm{C}$ (Jansen dkk., 2015). Pengobatan penurun demam atau antipiretik biasanya menggunakan parasetamol. Namun, untuk meminimalisir efek samping perlu menggunakan obat herbal yang memiliki senyawa sebagai penurun panas atau antipiretik.

Indonesia merupakan negara yang kaya akan sumber daya alamnya dan berkhasiat sebagai obat. Masyarakat Indonesia mulai memilih obat dari bahan alam dan kembali ke alam "Back to nature" karena selain aman digunakan efek samping yang dimiliki sangat kecil.Salah satu tanaman yang berkhasiat sebagai obat adalah tanaman mengkudu. Tanaman mengkudu berkhasiat sebagai larvasida, antioksidan, antimikroba, antikanker, menurunkan kolesterol darah, merangsang sistem kekebalan tubuh, penurunan kadar glukosa darah, antijamur, nutrisi, antibakteri dan sebagai antiinflamasi (Assi dkk., 2017).

Berdasarkan hasil skrining fitokimia daun mengkudu mengandung saponin, tanin, alkaloid, dan flavonoid (Utami, 2017). Berdasarkan penelitian Elysabet dan Rizkika (2018) bahwa daun mengkudu memiliki kandungan saponin, flavonoid, polifenol, tanin, dan triterpen. Seperti yang diketahui, flavonoid memiliki berbagai macam bioaktivitas yang ditunjukkan antara lain efek antipiretik, analgetik dan antiinflamasi (Mradu dkk., 2013). Pada penelitian Wiryawan yang menunjukan bahwa senyawa flavonoid dalam ekstrak bawang merah (Allium ascalonicum L.) menyebabkan penurunan suhu tubuh pada tikus putih yang mengalami demam. Senyawa flavonoid telah dikenal memiliki efek antiinflamasi dan juga memiliki efek antipiretik yang bekerja sebagai inhibitor cyclooxygenase (COX) yang berfungsi memicu pembentukan prostaglandin. Prostaglandin berperan dalam proses inflamasi dan peningkatan suhu tubuh. Apabila prostaglandin tidak dihambat maka terjadi peningkatan suhu tubuh yang akan mengakibatkan demam (Suwertayasa, 2013).

Hewan uji yang digunakan dalam penelitian ini adalah tikus putih jantan (Rattus norvegicus) galur wistar.Tikus jantan lebih diutamakan daripada tikus betina karena kondisi hormonal tikus jantan relatif lebih stabil sehingga tidak banyak mempengaruhi metabolisme di dalam tubuhnya (Baroroh dkk., 2011). Pepton 5\% dipilih sebagai penginduksi demam, karena pepton merupakan protein yang digunakan sebagai induser demam pada tikus.Demam dapat disebabkan gangguan otak atau akibat bahan toksik yang mempengaruhi pusat pengaturan suhu.Protein merupakan salah satu jenis pirogen yang dapat menyebabkan efek perangsangan terhadap pusat pengaturan suhu sehingga menimbulkan demam (Ibrahim dkk, 2014). Hal inilah yang melatar belakangi peneliti melakukan penelitian aktivitas antipiretik ekstrak etanol daun mengkudu (Morinda citrifolia L.) terhadap tikus putih jantan (Rattus norvegicus) galur wistar yang diinduksi pepton 5\%. 


\section{METODE PENELITIAN}

\section{Alat dan Bahan} infrared.

Alat-alat yang digunakan dalam penelitian adalah rotary evaporator dan thermometer

Bahan-bahan yang digunakan adalah daun mengkudu (Morinda citrifolia L.), pepton, parasetamol, etanol 70\%, Na. CMC, aquadest, tikus putih jantan (Rattus norvegicus) galur wistar.Simplisia yang digunakan adalah bagian daun dari tanaman mengkudu (Morinda citrifolia L.). Daun yang digunakan adalah daun yang tua dengan ciri-ciri daunnya bertangkai, berwarna hijau tua, duduk daun bersilang, berhadapan, 9 bentuknya bulat telur, lebar, sampai berbentuk elips, panjang daun $10-40 \mathrm{~cm}$, lebar $5-17 \mathrm{~cm}$, helai daun tebal, mengkilap, tepi daun rata, ujungnya meruncing, pangkal daun menyempit, tulang daun menyirip. Daun tua yang diambil dipilih yang telah membuka sempurna dan terletak di bagian cabang atau batang yang menerima sinar matahari sempurna karena pada saat itu terjadi fotosintesis sehingga kadar senyawanya tinggi, pada pagi hari. Pada penelitian ini, daun mengkudu diambil pada bulan Februari.

\section{Jalannya Penelitian}

\section{Penyiapan Simplisia}

Sampel berupa tanaman daun mengkudu (Morinda citrifolia L.) yang terlebih dahulu dilakukan pengumpulan bahan, kemudian dilakukan sortasi basah. Dicuci dengan air yang mengalir. Setelah dicuci, dikering anginkan selama 24 jam. Setelah itu dilakukan perajangan dan dikeringkan dengan cara diangin-anginkan selanjutnya disortasi kering. Simplisia kering daun mengkudu (Morinda citrifolia L.) disimpan dalam wadah yang kering dan tertutup rapat.

\section{Pembuatan Ekstrak}

Simplisia kering daun mengkudu dihaluskan menjadi serbuk simplisia, kemudian dimaserasi dengan menggunakan pelarut etanol $70 \%$ hingga terendam. Proses maserasi dilakukan selama $3 \times 24$ jam, diganti setiap $1 \times 24$ jam dengan pelarut yang sama. Setelah dimaserasi diperas sehingga mendapatkan maseratnya.Maserat tersebut dikentalkan dengan menggunakan alat rotary evaporator untuk mendapatkan ekstrak kental.

\section{Pembuatan Larutan Penginduksi Pepton 5\%}

Ditimbang 5 gram pepton, ditambahkan aquadest sedikit demi sedikit hingga larut dan masukkan ke dalam labu ukur $100 \mathrm{~mL}$, kemudian volumenya dicukupkan hingga $100 \mathrm{~mL}$ dengan menambahkan aquadest.

\section{Pembuatan Suspensi Na-CMC 1\%}

1 gram Na.CMC ditimbang, kemudian dikembangkan dengan cara ditaburkan di atas aquadest panas (suhu $70^{\circ} \mathrm{C}$ ) sebanyak $50 \mathrm{~mL}$ dan didiamkan selama 30 menit hingga diperoleh massa yang transparan, diaduk lalu diencerkan dengan aquadest hingga $100 \mathrm{~mL}$.

\section{Pembuatan Suspensi Parasetamol}

Tablet parasetamol digerus dan ditimbang serbuk parasetamol sebanyak $210 \mathrm{mg}$, ditimbang Na.CMC 1 gram dengan air corpus sebanyak $20 \times$ berat Na.CMC. Dikembangkan Na.CMC selama 30 menit, kemudian gerus hingga terbentuk massa yang transparan. Lalu masukkan serbuk parasetamol ke dalam lumpang, gerus hingga homogen kemudian tambahkan aquadest sampai volume $100 \mathrm{~mL}$.

\section{Penyiapan Hewan Uji}

Hewan uji yang digunakan pada penelitian ini belum diajukan Ethical klirens nya dari Lembaga kode etik penelitian yang terkait. Sebelum dilakukan percobaan, hewan uji diadaptasikan terlebih dahulu, tujuannya untuk memberikan adaptasi terhadap lingkungan yang baru. Hewan uji dipuasakan selama \pm 18 jam dan tetap diberi minum 
dengan air ad libitum sebelum perlakuan. Hewan uji dibagi dalam 5 kelompok, masing-masing kelompok terdiri dari 4 ekor tikus (Widyasari dan Ratika, 2017).

\section{Perlakuan Terhadap Hewan Uji}

Pengujian dilakukan dengan menggunakan 20 ekor tikus putih (Rattus norvegicus) jantan galur wistar, yang sebelumnya telah dipuasakan \pm 18 jam tetapi tetap diberi minum ad libitum setelah diberi tanda. Hewan uji dibagi menjadi 5 kelompok yang masing-masing terdiri dari 4 ekor tikus putih (Rattus norvegicus) jantan galur wistar.

\section{Uji Aktivitas Antipiretik}

Uji aktivitas antipiretik dilakukan dengan cara pengukuran suhu rektal pada semua hewan uji sebelum dan sesudah diinduksi dengan pepton 5\%. Hewan uji diinduksi secara peroral (P.O), pengukuran suhu pada rektal dilakukan pada lima kelompok uji coba yang terdiri dari kelompok larutan kotrol negatif, kelompok larutan kontrol positif (pembanding), sediaan uji kelompok 1, sediaan uji kelompok 2, dan sediaan uji kelompok 3. Diukur suhu awal (t(awal)) yaitu sebelum diinduksi pepton dan setelah diinduksi pepton selama satu jam, diukur kembali suhu rektal menggunakan thermometer infrared dengan satuan ${ }^{\circ} \mathrm{C}$, pada selang waktu $30^{\prime}, 60$, 90', 120', 150', 180', 210', 240 menit setelah penyuntikan untuk tiap kelompok konsentrasi lalu, dibandingkan dengan kontrol negatif dan kontrol positif untuk melihat aktivitas pada sediaan uji.

\section{Analisis Data} berikut:

Data yang diperoleh, kemudian dihitung \% daya antipiretik dengan cara sebagai

$$
\% \text { Daya Antipiretik }=\frac{t 0-t n}{t 0-t(\text { awal })} \times 100 \%
$$

$$
\begin{array}{ll}
\text { Keterangan: } \\
\text { t(awal) } & =\text { Suhu awal sebelum diinduksikan pepton } \\
\text { t0 } & =\text { Suhu demam setelah diinduksi pepton } \\
\text { tn } & =\text { Suhu pada menit ke }(30,60, \ldots \ldots, 240)
\end{array}
$$

Data yang diperoleh dilakukan uji homogenitas dan uji normalitas dengan kolmogrovsmirnov test, jika hasilnya terdistribusi normal dilanjutkan dengan uji one way anova dengan taraf kepercayaan 95\% (AA Styawan, 2015), dilanjutkan dengan uji lanjutan dengan LSD (Least Significant Difference) apabila terdapat perbedaan yang signifikan.

\section{HASIL DAN PEMBAHASAN}

Penelitian uji aktivitas antipiretik ini terdapat 5 kelompok perlakuan yang terdiri dari 3 kelompok dengan pemberian ekstrak etanol daun mengkudu dengan dosis $18 \mathrm{~g} / \mathrm{Kg} \mathrm{BB}, 36$ g/Kg BB, dan 72 g/Kg BB. Kelompok lainnya, yaitu diberikan Na.CMC 1\% sebagai kontrol negatif dan diberikan suspensi parasetamol sebagai kontrol positif. Parasetamol digunakan sebagai kontrol positif karena berfungsi sebagai kontrol yang memberikan efek dan akan dibandingkan dengan kontrol negatif yang tidak memiliki efek.

Parasetamol juga merupakan obat yang memberikan efek umum sebagai antipiretik. Parasetamol bekerja dengan cara menghambat enzim siklooksigenase yang berperan dalam mensintesis prostaglandin sehingga menurunkan suhu panas di hipotalamus. Pengamatan pertama dilakukan sebelum eksperimen untuk mengetahui suhu normal tikus putih. Pengamatan kedua dilakukan setelah 1 jam 30 menit pemberian pepton, untuk mengetahui peningkatan suhu tubuh tikus. Delapan pengamatan lainnya adalah pengukuran suhu untuk mengetahui efek perlakuan yang dilakukan 30', 60', 90', 120', 150', 180', 210', 240 menit setelah perlakuan. Hasil pengamatan daya antipiretik ekstrak etanol daun mengkudu pada tikus putih jantan setelah diinduksi pepton 5\% dapat dilihat pada Tabel I. 
Tabel I. Persentase Rata-Rata Daya Antipiretik Ekstrak Etanol Daun Mengkudu (Morinda citrifolia L.) pada Tikus Putih Jantan (Rattus norvegicus) Galur Wistar Yang Diinduksi Pepton 5\%

\begin{tabular}{clc}
\hline $\begin{array}{c}\text { Kelompok } \\
\text { Uji }\end{array}$ & \multicolumn{1}{c}{ Perlakuan } & $\begin{array}{c}\text { Rata-Rata } \\
\text { Daya Antipiretik }\end{array}$ \\
\hline 1 & Kontrol Negatif Na.CMC 1\% & $17 \pm 5,686$ \\
2 & Kontrol Positif Parasetamol & $73 \pm 7,228$ \\
3 & Ekstrak Etanol Daun Mengkudu & $33 \pm 33,376$ \\
& 18 g/ KgBB & \\
4 & Ekstrak Etanol Daun Mengkudu & $45 \pm 29,788$ \\
& 36 g/ KgBB & \\
5 & Ekstrak Etanol Daun Mengkudu & $80 \pm 34,160$ \\
\hline
\end{tabular}

Semua hewan uji yang mengalami peningkatan suhu tubuh sebesar atau sama dengan $0,6^{\circ} \mathrm{C}$ dapat dikategorikan demam. Hasil yang diperoleh pada tabel I menunjukkan adanya variasi suhu rata-rata pada setiap kelompok yang disebabkan oleh perbedaan perlakuan.Variasi dalam suatu kelompok perlakuan menunjukkan adanya faktor endogen masing-masing tikus yang bersifat individual terhadap agen pencetus demam dan banyak dipengaruhi oleh beberapa faktor non fisik dan lingkungan.

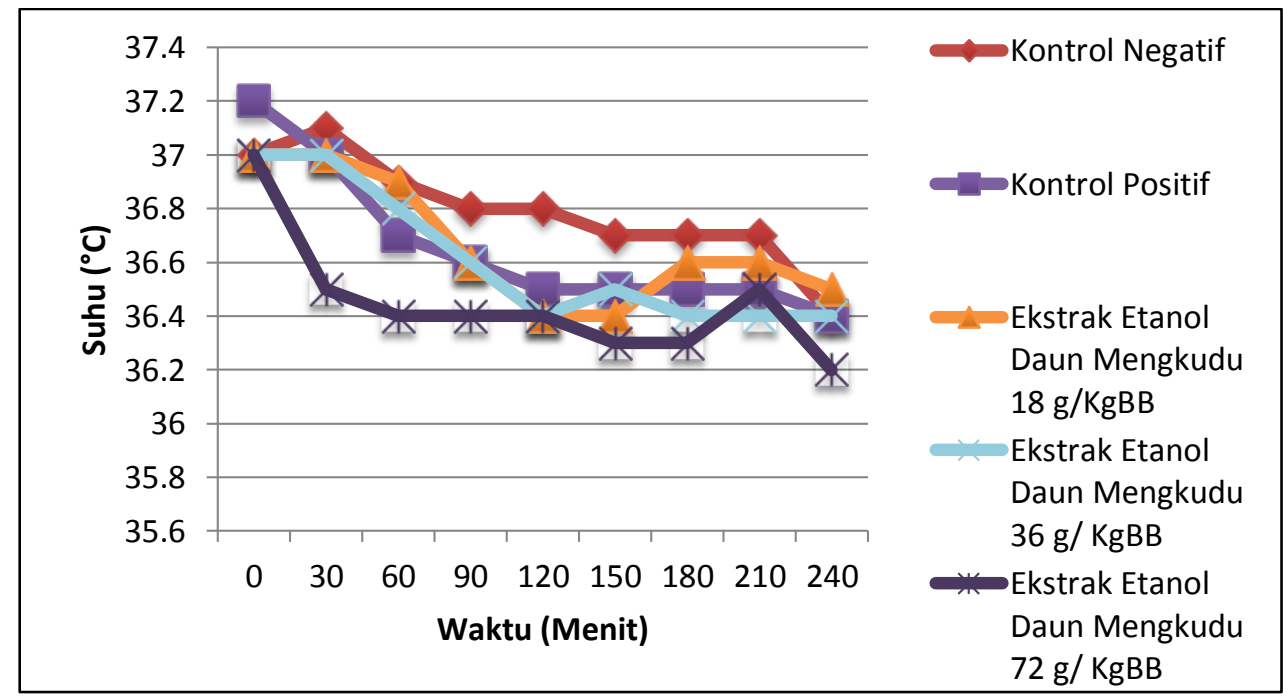

Gambar 1. Grafik Penurunan Rata-Rata Suhu Pengujian Aktivitas Antipiretik Ekstrak Etanol Daun Mengkudu (Morinda citrifolia L.) Terhadap Tikus Putih Jantan (Rattus norvegicus) Galur Wistar Yang Diinduksi Pepton 5\%

Berdasarkan gambar 1 diketahui perubahan suhu tubuh tikus putih dalam 8 waktu pengamatan. Kelompok tikus putih kontrol negatif mengalami peningkatan suhu tubuh dan tidak memiliki efek antipiretik. Adapun 4 kelompok tikus secara umum tampak mengalami peningkatan suhu tubuh setelah penginduksian pepton $5 \%$, kemudian diberikan perlakuan pada masing-masing kelompok menunjukkan penurunan suhu tubuh mulai tampak pada menit ke 30 setelah perlakuan.

Berdasarkan gambar 1 secara umum pada menit ke-60 aktivitas antipiretik mulai terlihat setelah diberikan perlakuan. Kemudian suhu tubuh tikus mulai mengalami penurunan 
hingga akhir pengamatan setelah perlakuan. Pada kelompok tikus putih kontrol positif, terjadi penurunan suhu yang cukup bermakna dikarenakan kadar puncak parasetamol dalam plasma darah dicapai dalam waktu 30-60 menit (Ganiswara, 2003).

Tabel II. Hasil Tes Normalitas, Homogenitas dan ANOVA

\begin{tabular}{cccc}
\hline No & Pengujian & Hasil analisa & Kesimpulan \\
\hline 1 & Normalitas & $\mathrm{P}=0,2>0,05$ & Normal \\
2 & Homogenitas & $\mathrm{P}=0,02>0,05$ & Homogen \\
3 & ANOVA & $\mathrm{P}=0,016<0,05$ & Berbeda bermakna \\
\hline
\end{tabular}

Perhitungan persen daya antipiretik menggunakan $t_{60}$ dikarenakan pada waktu 60 menit merupakan waktu yang optimal dalam mencapai puncak demam.

Tabel III. Hasil Uji LSD Persentase Daya Antipiretik Ekstrak Etanol Daun Mengkudu (Morinda citrifolia L.) Terhadap Tikus Putih Jantan (Rattus norvegicus) Galur Wistar Yang Diinduksi Pepton 5\%

\begin{tabular}{|l|l|l|l|}
\hline Perlakuan & Perlakuan & $\begin{array}{l}\text { Nilai } \\
\text { Sign }\end{array}$ & Kesimpulan \\
\hline \multirow{4}{*}{ Kontrol Positif } & Kontrol Negatif & $0.008^{*}$ & Berbeda signifikan \\
\cline { 2 - 4 } & Dosis 1 & $0.044^{*}$ & Berbeda signifikan \\
\cline { 2 - 4 } & Dosis 2 & 0.145 & Tidak Berbeda signifikan \\
\cline { 2 - 4 } & Dosis 3 & 0.703 & Tidak Berbeda signifikan \\
\hline \multirow{4}{*}{ Kontrol Negatif } & Kontrol Positif & $0.008^{*}$ & Berbeda signifikan \\
\cline { 2 - 4 } & Dosis 1 & 0.393 & Tidak Berbeda signifikan \\
\cline { 2 - 4 } & Dosis 2 & 0.143 & Tidak Berbeda signifikan \\
\cline { 2 - 4 } & Dosis 3 & $0.003^{*}$ & Berbeda signifikan \\
\hline \multirow{2}{*}{$\begin{array}{l}\text { Ekstrak daun mengkudu } \\
\text { (Dosis 18 g/KgBB }\end{array}$} & Kontrol Positif & $0.044^{*}$ & Berbeda signifikan \\
\cline { 2 - 4 } & Kontrol Negatif & 0.393 & Tidak Berbeda signifikan \\
\cline { 2 - 4 } & Dosis 2 & 0.516 & Tidak Berbeda signifikan \\
\cline { 2 - 4 } & Dosis 3 & $0.020^{*}$ & Berbeda signifikan \\
\hline \multirow{2}{*}{$\begin{array}{l}\text { Ekstrak daun mengkudu } \\
\text { dosis 36 g/KgBB } \\
\text { (Dosis 2) }\end{array}$} & Kontrol Positif & 0.145 & Tidak Berbeda signifikan \\
\cline { 2 - 4 } & Kontrol Negatif & 0.143 & Tidak Berbeda signifikan \\
\cline { 2 - 4 } & Dosis 1 & 0.516 & Tidak Berbeda signifikan \\
\cline { 2 - 4 } & Dosis 3 & 0.073 & Tidak Berbeda signifikan \\
\hline \multirow{2}{*}{$\begin{array}{l}\text { Ekstrak daun mengkudu } \\
\text { dosis 72 g/KgBB } \\
\text { (Dosis 3) }\end{array}$} & Kontrol Positif & 0.703 & Tidak Berbeda signifikan \\
\cline { 2 - 4 } & Kontrol Negatif & $0.003^{*}$ & Berbeda signifikan \\
\cline { 2 - 4 } & Dosis 1 & $0.020^{*}$ & Berbeda signifikan \\
\cline { 2 - 4 } & Dosis 2 & 0.073 & Tidak Berbeda signifikan \\
\hline
\end{tabular}

Keterangan : * berbeda signifikan terhadap kontrol (taraf kepercayaan 95\%)

Langkah sebelum dilakukan analisis statistik menggunakan uji one way anova terlebih dahulu dilakukan analisis data apakah terdistribusi normal dan homogen. Tabel II menunjukkan hasil tes normalitas, homogenitas dan Anova.

Hasil analisis Anova persentase daya antipiretik ekstrak etanol daun mengkudu (Morinda citrifolia L.) pada tikus putih jantan yang diinduksi pepton 5\% dapat dilihat pada Tabel III. Pada 3 kelompok perlakuan memperlihatkan aktivitas antipiretik berupa penurunan suhu.

Ekstrak etanol daun mengkudu (Morinda citrifolia L.) dosis 72 g/ KgBB memiliki aktivitas antipiretik setara dengan suspensi parasetamol sebagai kontrol positif dengan 
persen daya antipiretik sebesar $80 \%$ dan nilai $p$ value 0,703 ( $p>0,05)$, sedangkan pada kontrol negatif dengan persen daya antipiretik sebesar $17 \%$ dan nilai $\mathrm{p}$ value $0,003 \%$ $(\mathrm{p}<0,05)$. Aktivitas antipiretik ekstrak daun mengkudu diduga karena adanya kandungan flavonoid pada ekstrak daun mengkudu. Hal ini berbanding lurus dengan hasil penelitian Wiryawan (2014) yang menunjukan bahwa senyawa flavonoid dalam ekstrak bawang merah (Allium ascalonicum L.) menyebabkan penurunan suhu tubuh pada tikus putih yang mengalami demam. Hal yang sama juga ditunjukan pada penelitian Nysa (2017) yang menunjukan bahwa senyawa flavonoid pada ekstrak air umbi bengkuang (Pachyrhizus erosus) menyebabkan penurunan suhu tubuh pada Mencit (Mus musculus) Model Hiperpireksia. Golongan senyawa yang diduga bertanggung jawab terhadap aktivitas antipiretik adalah flavonoid yang berkerja dengan menghambat enzim siklooksigenase (Hartini, 2012). Flavonoid dapat menghambat enzim siklooksigenase khususnya siklooksigenase-2 yang berperan dalam biosintess prostaglandin sehingga demam terhambat (Robinson, 1995). Hal lain yang mempengaruhi penurunan suhu tubuh adalah peningkatan dosis secara umum memiliki makna terhadap peningkatan aktivitas penurunan suhu tubuh. Selain flavonoid, efek antipiretik dari ekstrak daun mengkudu juga mungkin disebabkan oleh kandungan kimia lainnya. Oleh karena itu, perlu dilakukan penelitian lebih lanjut mengenai kandungan kimia lain yang berperan sebagai antipiretik dan mekanisme kerjanya.

\section{KESIMPULAN}

Berdasarkan dari hasil penelitian dan analisis data yang telah dilakukan maka dapat disimpulkan bahwa ekstrak etanol daun mengkudu (Morinda citrifolia L.) mempunyai aktivitas sebagai antipiretik terhadap tikus putih jantan (Rattus norvegicus) galur wistar yang diinduksi pepton 5\%. Ekstrak etanol daun mengkudu (Morinda citrifolia L.) dosis 72 $\mathrm{g} / \mathrm{KgBB}$ memiliki kemampuan aktivitas sebagai antipiretik yang paling baik terhadap tikus putih jantan (Rattus norvegicus) galur wistar yang diinduksi pepton 5\%.

\section{UCAPAN TERIMAKASIH}

Peneliti mengucapkan terimakasih kepada Akademi Farmasi Yarsi Pontianak atas semua kontribusinya selama penelitian berlangsung.

\section{DAFTAR PUSTAKA}

Assi, R.A, dkk.2017. Morinda citrifolia (Noni): A Comprehensive Review On Its Industrial Uses., Pharmacological Activities., And Clinical Trials. Arabian Journal of Chemistry.10:691-707.

Baroroh F., Nurfina A., Hari, S. 2011. Uji Efek Antihiperglikemik Ekstrak Etanol Daun Kacapiring (Gardenia augusta, Merr) Pada Tikus Putih Jantan Galur Wistar. Jurnal Ilmiah Kefarmasian.1 (1) : 43-53.

Djauhariya, E. 2003. Mengkudu (Morinda citrifolia L.) Tanaman Obat Potensial. Balai Penelitian Tanaman Rempah dan Obat. Pengembangan Teknologi TRO 15(1) : 1-16.

Elysabet, H dan Rizkika, T. NA. 2018. Potensi Bahan Herbal Ekstrak Etanol Daun Mengkudu Asal Desa Wajak Lor, Tulungagung, Jawa Timur Terhadap Bakteri Penyebab Jerawat. Universitas Nusantara PGRI Kediri. JuKe Vol. 2 No. 2.

Ganiswara, S.G., Setiabudy, R., Suyatna, F.D. 2003. Farmakologi dan Terapi.Vol 4.IU pres, Jakarta.571-572.

Hartini. 2012.Topical Application of Ethanol Extract of Starfruit Leaves (Averrhoa blimbi L.) Increases Fibroblasts in Gingival Wounds Healing of White Male Rats. Journal of Biomedical Science.6 (1) :35-39. 
Ibrahim, N., Yusriadi., Ihwan/ 2014. Uji Efek Antipieretik Kombinasi Ekstrak Etanol Herba Sambiloto (Andrographis paniculata Burm.f. Nees.) dan Belimbing Wuluh (Averrhoa bilimbiL.) Pada Tikus Putih Jantan (Rattus norvegicus). Online Jurnal of Natural Science.3(3): $257-268$.

Jansen, I., Jane,W., dan Henoch, A. 2015. Uji Efek Antipiretik Ekstrak Meniran (Phyllantus niruriL.) Pada Tikus Wistar (Rattus norvegicus) Jantan Yang Di Induksi Vaksin DPTHB, Jurnal e-Biomedik (eBm).3 (1) : 470-474.

Mradu, G., Dalia, B., Arup, M. 2013. Studies of Anti-Inflammatory, Antipyretic and Analgesic Effect of Aqueous Extract of Traditional Herbal Drug on Rodents. Journal Internasional Research of Pharmacy.4(3):113-120.

Nysa, R.A.Z., Herri, S.S., Miranti, K. 2017. Uji Efek Antipiretik Ekstrak Air Umbi Bengkuang (Pachyrhizus erosus) pada Mencit (Mus musculus) Model Hiperpireksia, Universitas Islam Bandung. Bandung Meeting on Global Medicine \& Health (BaMGMH), Vol. 1 No. 1.

Robinson, T. 1995. Kandungan Organik Tumbuhan Tinggi. Vol 4.Terjemahan Kosasih Padmawinata. ITB Press. Bandung.347-367.

Suwertayasa, I.M.P., Widdhi, B., Hosea, J.E. 2013. Uji Efek Antipiretik Ekstrak Etanol Daun Tembelekan (Lantana Camara L.) Pada Tikus Putih Jantan Galur Wistar, Pharmacon Jurnal Ilmiah Farmasi.2 (3) : 45-49.

Utami S.P, 2017, Efek Antidiabetes Fraksi Air, Asetat, dan n-Heksan Daun Mengkudu (Morinda citrifolia L.) Pada Mencit Jantan (Mus musculus) yang Diinduksi Aloksan, Artikel.1-14.

Widyasari Ratna., Ratika Ratiningsih, 2017,Uji Aktivitas Antipiretik Ekstrak Etanol Kulit Jeruk Manis (Citrus x aurantium L.)Terhadap Tikus Putih (Rattus novergicus) Jantan Galur Wistra Yang Diinduksi Pepton 5\%. Jurnal Ilmiah Ibnu Sina. 2 (2) :204-213.

Wiryawan, I.G.A. 2014. Efek Ekstrak Bawang Merah ( Allium ascalonicum L.) Terhadap Perubahan Suhu Tubuh Pada Tikus Putih (Rattus Norvegicus) Yang Mengalami Demam. Skripsi. 